\title{
Integrated Management Planning in Canada's Northern Marine Environment: Engaging Coastal Communities
}

\author{
SARA EDDY, ${ }^{1}$ HELEN FAST $^{2}$ and THOMAS HENLEY ${ }^{3}$
}

(Received 16 May 2000; accepted in revised form 19 November 2001)

\begin{abstract}
In accordance with international law and custom, Canada declared an exclusive economic zone of 2.9 million $\mathrm{km}^{2}$ when it passed the Oceans Act in 1997. Extensive resource management responsibilities were associated with this declaration. An early effort to engage a northern coastal community in the first stages of an integrated management planning process focused on the small northern community of Churchill, Manitoba, and a $150 \mathrm{~km}$ stretch of the Hudson Bay coastline. The steps taken included communicating the importance of management planning for the town's coastal region; conducting personal interviews on coastal activities and concerns with a representative sample of the community; consolidating, tabulating, and mapping the results of these interviews; verifying results with the community; and evaluating the effectiveness of the process used. The approach taken, as well as the weeks spent living in the community, were important factors in developing a relationship of trust between the researcher and the community. Those interviewed were more comfortable participating once they had had a number of opportunities to become familiar with the context of the study, its relevance to them, and the researcher.
\end{abstract}

Key words: integrated management planning, Oceans Act, community engagement, Churchill, Manitoba, northern Canada, Hudson Bay

RÉSUMÉ. En adoptant la Loi sur les océans en 1997, le Canada a déclaré une zone économique exclusive de 2,9 millions de km², en vertu du droit international. D'importantes responsabilités de gestion des ressources étaient rattachées à cette déclaration. Une première tentative visant à amener une communauté côtière du Nord à participer aux étapes préliminaires d'un processus de planification de gestion intégrée a porté sur la petite collectivité nordique de Churchill, au Manitoba, et sur un tronçon de $150 \mathrm{~km}$ du rivage de la baie d'Hudson. Les démarches entreprises comprenaient: la communication de l'importance de la planification de la gestion pour la région côtière de la ville; la réalisation d'entrevues personnelles sur les activités et les enjeux reliés à la côte avec un échantillon représentatif de la communauté; le regroupement, la compilation et la représentation cartographique des résultats de ces entrevues; la vérification des résultats de concert avec la collectivité; ainsi que l'évaluation de l'efficacité de la méthode suivie. L'approche utilisée, de même que les semaines vécues au sein de la communauté, étaient des facteurs importants dans le développement d'une relation de confiance entre le chercheur et la collectivité. Les répondants étaient plus à l'aise pour participer, après avoir eu diverses occasions de se familiariser avec le contexte de l'étude, sa pertinence à leur égard, ainsi que la personne menant la recherche.

Mots clés: planification de la gestion intégrée, Loi sur les océans, mobilisation communautaire, Churchill, Manitoba, Nord canadien, baie d'Hudson

Traduit pour la revue Arctic par Nésida Loyer.

\section{INTRODUCTION}

Canada is a maritime nation. It has one of the world's largest continental shelves ( 3.7 million $\left.\mathrm{km}^{2}\right)$ and the world's longest coastline, extending almost $250000 \mathrm{~km}$ along three oceans: the Atlantic, the Pacific, and the Arctic (Haward and VanderZwaag, 1995; DFO, 1998; NRTEE, 1998). Eight of Canada's 10 provinces and all three of its territories have marine coastal dimensions that encompass enormous geographic and environmental diversity, in addition to supporting substantial social and economic systems (Environment Canada, 1994; DFO, 1998). Seven million Canadians live in coastal communities along these waters (Environment Canada, 1994).

Consistent with marine management responsibilities related to these resources, Canada is party to numerous ocean-related international conventions, which deal with shipping, fisheries, biodiversity, and pollution. Examples

\footnotetext{
${ }^{1}$ Natural Resources Institute, University of Manitoba, 70 Dysart Road, Winnipeg, Manitoba R3T 2N2; present address: Fisheries and Oceans Canada, Ontario-Great Lakes Area, Habitat Management Program, 867 Lakeshore Road, Burlington, Ontario L7R 4A6, Canada; eddys@dfo-mpo.gc.ca

${ }^{2}$ Fisheries and Oceans Canada, Oceans Programs Division, 501 University Crescent, Winnipeg, Manitoba R3T 2N6, Canada; fasth@dfo-mpo.gc.ca

${ }^{3}$ Natural Resources Institute, University of Manitoba, 70 Dysart Road, Winnipeg, Manitoba R3T 2N2, Canada; henley@ ms.umanitoba.ca (C) The Arctic Institute of North America
} 
include the United Nations Convention on Biological Diversity, the United Nations Framework Convention on Climate Change, the World Heritage Convention, the Constitution of the World Meteorological Organization, the International Convention for the Prevention of Pollution from Ships, and the Convention on the Prevention of Marine Pollution by Dumping of Wastes and Other Matter (DFO, 1997).

In accordance with customary international law, Canada declared an exclusive economic zone of 2.9 million $\mathrm{km}^{2}$ when it passed the Oceans Act (Canada, 1997). Management responsibilities associated with this declaration encompassed issues of leadership, sovereignty, trade, northern development, industrial development, transportation, health, environment, and acquiring the scientific and traditional knowledge needed to reduce uncertainty about marine ecosystem dynamics.

The Oceans Act is not primarily prescriptive in delegating management responsibilities to the Minister of Fisheries and Oceans. Rather, it challenges the Department of Fisheries and Oceans to consult widely and work collaboratively with all interested parties to develop an ocean management strategy. Successful implementation of the Act depends on gaining the support of 22 other federal departments and agencies with ocean-related responsibilities. It also depends on the support of other levels of government, industry, boards and agencies, aboriginal organizations, coastal communities, and other persons and bodies with interests in these resources (Oceans Act, Section 31). The expectation is that these groups will work together to develop an ocean management strategy that will ensure the sustainable development of Canada's marine resources.

The scale of effort required to develop management processes for Canada's large ocean areas is daunting. The complexities of interests, levels of responsibility, and jurisdiction are numerous and, in some important respects, unique to Canada. To advance marine management processes in support of or in conjunction with policy and strategy development, those involved in Canada's ocean management efforts for the Department of Fisheries and Oceans have adopted a "learn by doing" approach. In other words, information concerning integrated management efforts in one region is regularly shared with staff in other regions.

\section{INTEGRATED MANAGEMENT IN THE CANADIAN CONTEXT}

The Oceans Act states that "the Minister [of Fisheries and Oceans] shall lead and facilitate the development and implementation of plans for the integrated management of all activities or measures in or affecting estuaries, coastal waters and marine waters that form part of Canada or in which Canada has sovereign rights under international law" (Section 31, paragraph 31). Further, the Act directs that such management planning be undertaken "in collaboration with other ministers, boards and agencies of the Government of Canada, with provincial and territorial governments and with affected aboriginal organizations, coastal communities and other persons and bodies, including those bodies established under land claims agreements" (Section 31, paragraph 29). The working definition developed under the Oceans Act is that integrated management (IM) is a continuous process through which decisions are made for the sustainable use, development, and protection of coastal, estuarine, and marine areas and resources. IM acknowledges the interrelationships that exist among coastal and ocean uses and the environments they potentially affect. It is designed to overcome the fragmentation inherent in a sectoral management approach. IM analyzes the implications of development, identifies conflicting uses, and promotes linkages and harmonization among sectoral coastal and ocean activities.

This working definition recognizes the importance of commitment to citizen engagement across Canada in the broadest sense. Communicating the importance of developing ocean management strategies to far-flung populations of several hundreds or thousands of people in remote northern regions is a difficult challenge. Many of these communities have a strong oral tradition, and written documents are not effective means of communication. In many communities, the language of choice is neither of Canada's two official languages. Engaging the interest of coastal community residents depends on distilling the abstract concepts of ocean management into observable benefits relevant to northern experiences and then developing effective communication strategies. Establishing credibility and gaining support require a long-term commitment. High travel costs, lengthy distances to be covered, and a harshly unpredictable climate compound the difficulties of communicating effectively with northern communities - and ultimately securing their participation.

The methods we used to engage a northern coastal community in the integrated management process were adapted from community engagement efforts in the St. Lawrence River in southern Canada (Lalumière and Morisset, 1998).

\section{ENGAGING NORTHERN COASTAL COMMUNITIES}

The purpose of this research was to develop, implement, and evaluate a model process for engaging northern coastal communities early in the integrated management process. Five stages typical of integrated management planning are 1) defining and assessing a management area; 2 ) engaging affected parties; 3 ) developing an integrated management plan; 4) implementing the plan; and 5) monitoring and evaluating outcomes (adapted from European Commission, 1999; Kay and Alder, 1999). These stages may be carried out concurrently, sequentially, or iteratively, as appropriate in specific situations. In any case, the first two stages are interdependent to a significant degree. 
One cannot confidently identify all interested parties until the management area has been specified; however, to define the boundaries of their work, planners need to know the scale and scope of management issues as perceived by coastal communities.

The first step of this study was to communicate effectively the importance of management planning for the town's coastal region and to explain how the Oceans Act can help communities participate in this planning effort. Individuals were given the opportunity to discuss the intent of the Oceans Act and ask questions about its relevance to their community. Once this stage was completed, they were asked whether they wished to participate further by identifying the important issues related to coastal resource management and thus help indirectly to define management boundaries for future planning efforts.

\section{THE STUDY AREA: CHURCHILL COASTLINE, PROVINCE OF MANITOBA}

The focus of the study was the $150 \mathrm{~km}$ coastline extending from Button Bay to Cape Churchill on either side of the community of Churchill, Manitoba (population 1000), the only permanent community on Manitoba's $1400 \mathrm{~km}$ coastline (Fig. 1). First Nations (Cree, Dene, and Métis) and Inuit residents comprise approximately $60 \%$ of Churchill's population (Manitoba Housing Authority, 1999). Ecologically, the coast is a mixture of tundra, taiga, boreal, and marine biomes. It is important as habitat for a number of species, most notably polar bear (Ursus maritimus), beluga (Delphinapterus leucas), caribou (Rangifer sp.), waterfowl, geese, and other avian species (Caribou Ventures Limited, 1994).

The Hudson Bay coastline represents important social and cultural values, in terms of historical sites and the recreational and traditional activities that are important aspects of life for many people in Churchill. Aboriginal peoples have frequented the region for many centuries, as the numerous artifacts found throughout the coastal area attest (Beals, 1968). European explorers founded a fur trading post at the town site; the post existed from the 1600s until the early 1900s, and evidence of it remains at Fort Prince of Wales and Sloop's Cove. The construction of a railway to Hudson Bay, completed in 1929, brought shipping to the region. Military installations and a research rocket range followed; all are now defunct, but their remains are prominent around the town (Newton, 2000). Abundant wildlife and trail access make the coast an important part of town life for harvesting, hunting, and social activities.

The local economy depends on shipping and tourism to a significant degree. Canada's northernmost deepwater port is located here, on the Churchill River (Churchill Task Force, 1995; Newton, 2000). The port and its facilities make Churchill an important rail and shipping transportation centre for the province of Manitoba. Agricultural products have been moved from central Canada through Churchill for the past 70 years. The port is also used as a staging area for resupply, particularly of fuel and food, to the Kivalliq region of the Nunavut Territory (KGS Consulting, 1998). Shipments from the port have recently been expanded to include the export of minerals and specialty crops to northern Europe and Russia (Caribou Ventures Limited, 1994; Churchill Task Force, 1995). The capacity and potential exist to import products, such as minerals for processing and phosphates for fertilizer, and such imports have been identified as an important development opportunity (Newton, 2000). Shipping is a major employer in the community, with 100 workers employed by the Hudson Bay Port Company during the July to November shipping season. An additional 40 are employed by the Northern Transportation Company Limited, which operates its barges from the port (Newton, 2000). The port contributes an estimated $\$ 6.5$ million annually to the local economy (LGD of Churchill, 1996).

Tourism activities, primarily observing polar bears and belugas, viewing northern lights, and birdwatching, are also important contributors to Churchill, by some estimates accounting for at least $40 \%$ of the local economy (Town of Churchill, 1999). In 1996, 12000 visitors arrived in Churchill by air and an additional 6500 by rail (LGD of Churchill, 1996). More visitors are expected to arrive via ocean cruise ships, which have been frequenting Churchill as a port of call in recent years. Further growth of tourism is currently limited by infrastructure (Newton, 2000).

\section{METHODS}

The methods used for this study were based on an integrated management project conducted by Lalumière and Morisset (1998) for the St. Lawrence Upper North Shore in the Province of Quebec. A Coastal Committee of local stakeholders, including all levels of government, First Nations, community organizations, and industry representatives, was formed to select management boundaries for the $85 \mathrm{~km}$ management area and identified its land border as $2-3 \mathrm{~km}$ inland and its seaward border as $10 \mathrm{~km}$ offshore. During its meetings, the committee divided the coastal management area into management units, identified on the basis of both natural and human-use features. The committee prioritized the management units and then identified and mapped activities and concerns within those units.

The unit approach is consistent with that of previous studies, in which classifying coastal areas into management or study units was found to allow more flexibility in identifying and addressing issues. By examining areas of the coast individually, planners can define issues at an appropriate and manageable scale, and then relate them to the larger coast (Institute for Research on Environment and Economy, 1996). For the present study, we refer to the management units as "study units" in order to differentiate them from other existing management regimes. 


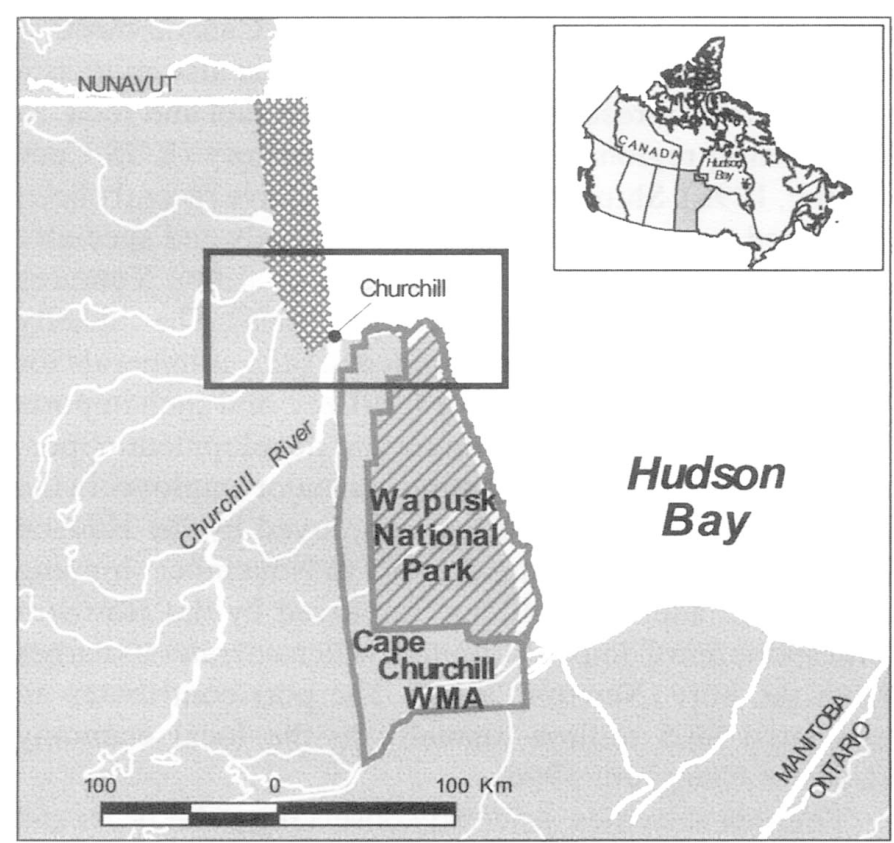

FIG. 1. Manitoba's marine coastline.

\section{ENGAGING COASTAL RESIDENTS}

\section{Preliminary Site Visit}

The authors made an introductory site visit to Churchill to gain familiarity with the study area, conduct preliminary meetings with interested parties, and promote awareness of the Oceans Act and this project within the community. Preliminary interviews were conducted with 22 individuals, who presented a general overview of resource activities and concerns in the area. These interviews also provided insight into which members of the community should be included in the project and which additional sectors of the community needed to become involved. The interviewees suggested specific names and organizations to be involved in the project.

Selection of initial contacts during the site visit was based on the researcher's previous knowledge of the town's prominent organizations and industries. Information sheets detailing the Oceans Act and the study were provided to these contacts and discussions concerning the relevance of these two initiatives to Churchill ensued. Community members viewed Hudson Bay and the coastal activities (such as shipping and tourism) as crucial to the town's well-being, so they recognized the importance of identifying and managing these activities in order to sustain the coastal environment and avoid resource-use conflicts. The Oceans Act and this study were often seen as being of immediate relevance to the region during these discussions.

\section{The Study}

The snowball sampling technique, in which known contacts suggest other people and organizations to participate in a study, was used to identify individuals to be interviewed who were representative of interested parties in Churchill. Interviews were structured around open-ended, or qualitative, questions. The snowball sampling method is often used in qualitative field research to target individuals possessing specific characteristics (Babbie, 1998) and is known to be an effective way of identifying specific individuals who might not otherwise be easily located. One drawback is that it may result in statistically unrepresentative sample populations. For this reason, it is used primarily for exploratory purposes (Babbie, 1998). For this study, individuals with knowledge and experience relevant to coastal resource-use activities and concerns were sought.

The total number of individuals to be interviewed for the study was estimated on the basis of several factors, including the size of the community, the level of interest shown during the initial site visit, and the community sectors to be involved in the study, as suggested by the sampling technique. This estimate proved to be consistent with the level of convergence that occurred among the 43 interviews conducted, suggesting that the majority of existing concerns and resource-use activities had been identified. Interview participants represented academia, aboriginal groups, economic interests, governments (municipal, provincial, and federal), and general community members.

\section{DEFINING AND ASSESSING MANAGEMENT AREAS}

In preparation for the interviews, the coastal area extending from Button Bay to Cape Churchill was divided into study units. The factors considered in defining study units included 1) natural discontinuities in the shoreline, which act to separate certain features from others (e.g., estuaries and bays were considered as individual study units); 2) administrative boundaries, such as those formed by the boundary of Wapusk National Park; 3) human settlement boundaries that designate the areas most affected by human use activities, such as the Town of Churchill; 4) areas of intensive activities, such as the area that encompasses the tundra vehicle routes used for polar bear tourism; and 5) ecological considerations, such as areas of important habitat and diversity (for example, the polar bear staging area at Cape Churchill).

Eleven study units were identified (see Table 1; Fig. 2):

1. Button Bay. This prominent bay is located west of the town and the Churchill River. It is one of the few areas of the coast used for recreational fishing and boating, because of its protected nature. It provides habitat for belugas, polar bears, birds, and moose (Alces alces), as does much of this stretch of coastline.

2. Western Shore of Churchill River. Located between Button Bay and the Churchill River, this unit contains many historical remains from aboriginal and European settlements and provides habitat for caribou, birds, polar bears, and belugas. Current human 
TABLE 1. Study units and boundaries.

\begin{tabular}{|c|c|c|c|}
\hline Unit & Represented Area & Justification & Boundaries \\
\hline 1 & Button Bay & Natural discontinuity (bay) & $\begin{array}{l}\text { West }=\text { Dymond Lake, } \\
\text { East }=\text { Seahorse Gully }\end{array}$ \\
\hline 2 & Western shore of Churchill River & Cultural and ecological significance & $\begin{array}{l}\text { West }=\text { Seahorse Gully, } \\
\text { East }=\text { shore of Churchill River and Eskimo Point }\end{array}$ \\
\hline 3 & Churchill River Estuary & Ecological importance and intensive activities (port) & $\begin{array}{l}\text { West }=\text { Churchill River, } \\
\text { East }=\text { Churchill River and Port }\end{array}$ \\
\hline 4 & Town of Churchill & Human settlement & $\begin{array}{l}\text { West }=\text { Port of Churchill, } \\
\text { East }=\text { Water treatment plan }\end{array}$ \\
\hline 5 & $\begin{array}{l}\text { Outskirts of town and eastern } \\
\text { shore of Churchill River }\end{array}$ & Intensive human activities & $\begin{array}{l}\text { West }=\text { Water treatment plant, } \\
\text { East }=\text { Incinerator }\end{array}$ \\
\hline 6 & Distant outskirts of town & Moderately intensive human activities & $\begin{array}{l}\text { West }=\text { Incinerator, } \\
\text { East = Cape Churchill WMA }\end{array}$ \\
\hline 7 & Bird Cove & Natural discontinuity (bay) and ecological importance & $\begin{array}{l}\text { West }=\text { Cape Churchill WMA, } \\
\text { East }=\text { Halfway Point }\end{array}$ \\
\hline 8 & Gordon Point & Intensive human activities (polar bear tourism) & $\begin{array}{l}\text { West }=\text { Halfway Point } \\
\text { East }=\text { Eastern edge of Gordon Point }\end{array}$ \\
\hline 9 & Knight's Hill & Extent of most human activities & $\begin{array}{l}\text { West }=\text { Eastern edge of Gordon Point, } \\
\text { East }=\text { Wapusk National Park }\end{array}$ \\
\hline 10 & La Perouse Bay & $\begin{array}{l}\text { Natural discontinuity (bay) and ecological importance } \\
\text { (snow geese) }\end{array}$ & $\begin{array}{l}\text { West }=\text { Wapusk National Park, } \\
\text { East }=\text { Eastern edge of La Perouse Bay }\end{array}$ \\
\hline 11 & Cape Churchill & Ecological importance (polar bear) & $\begin{array}{l}\text { West }=\text { Eastern edge of La Perouse Bay, } \\
\text { East }=\text { Hudson Bay }\end{array}$ \\
\hline
\end{tabular}

activities, which are centred on tourism, include birdwatching, hiking, and touring the historical sites.

3. Churchill River Estuary. Comprising the river and the site of the Hudson Bay Port Company, this unit encompasses all shipping activities. It is also important habitat for belugas, which are thought to use it for moulting and feeding during their annual migration. Beluga tourism is centred in this area, and boating and fishing are popular recreational activities.

4. Town of Churchill. Since Churchill is the only community located on Manitoba's Hudson Bay coast, this is the unit of most intensive human use.

5. Outskirts of Town and Eastern Shore of the Churchill River. Bounded to the west by the town and to the east by the town incinerator, this unit is used intensively by humans for secondary settlements, gravel and sand excavation, the local airport, and all waste management activities. Birdwatching is popular in this area, as are hunting and trapping.

6. Distant Outskirts of Town. This unit, located between the town incinerator and the western boundary of the Cape Churchill Wildlife Management Area, is subject to moderately intensive human activities, primarily for trail access, hunting, and trapping.

7. Bird Cove. Located entirely within the Cape Churchill Wildlife Management Area, this moderately prominent bay provides critical habitat for many avian species and is an important birdwatching site. There are many recreational cabins located in this unit, used primarily by local residents.

8. Gordon Point. Bounded by Bird Cove and the eastern edge of Gordon Point, this unit is the site of intensive human use for polar bear tourism. The primary routes of the tundra vehicles bringing tourists to seek out polar bears are all located within this area.

9. Knight's Hill. The eastern edge of this unit is the Wapusk National Park boundary, which marks the extent of most human uses because of the difficulty of travelling over the extensive wetlands to the east. During the winter months, however, the area is used for trapping and hunting. Scientific research through the Churchill Northern Studies Centre is pursued annually in this area.

10. La Perouse Bay. This prominent bay is used extensively by snow geese (Chen caerulescens) and by researchers studying the impact of the geese on tundra vegetation (Cooke et al., 1995).

11. Cape Churchill. Located between La Perouse Bay to the west and Hudson Bay to the east, this unit is critically important as a staging area for polar bears each fall prior to freeze-up (Lunn et al., 1997).

Describing study unit boundaries necessitated defining the extent of the land-sea interface to be used for this study. In coastal literature, the coastal zone is considered to include the area stretching from the highest terrestrial tidal level to the edge of the continental shelf, including rivers, estuaries, and drainage catchments, along with the beds and shorelines of such water bodies (Cayer and Biagi, 1994; Wildish and Strain, 1994). While ideally management planning boundaries should be defined by determining the extent of the relevant interactions of biophysical, economic, and social factors, delimiting such boundaries often is constrained by the impracticality of using such large scales (Scura et al., 1992). Designating manageable onshore and offshore boundaries can help provide 


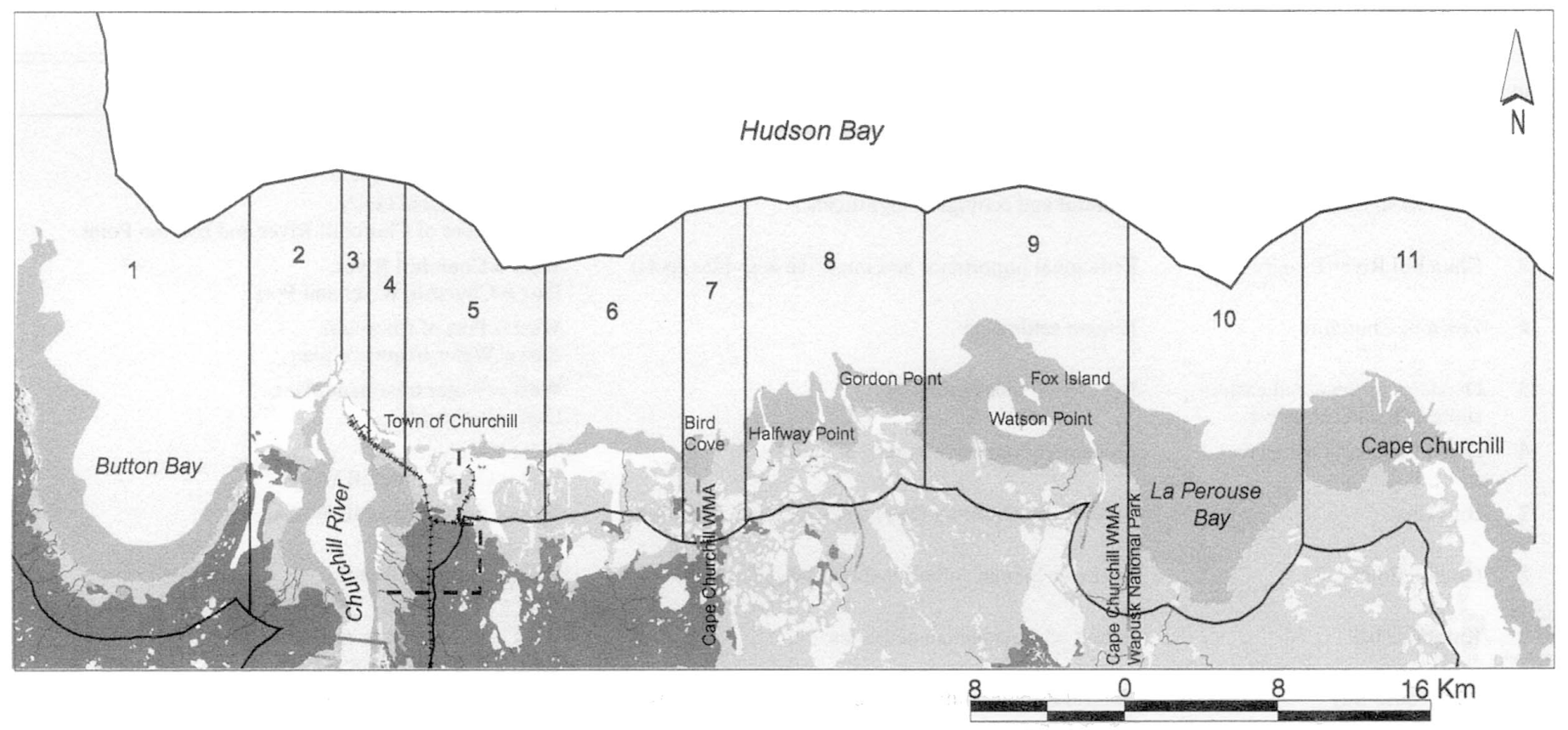

FIG. 2. Study unit boundaries, Button Bay to Cape Churchill, Manitoba.

meaningful management objectives and results, keeping the focus on the land-sea interface. Cicin-Sain and Knecht (1998) recommend use of a narrow inland boundary that embraces the majority of activities. Regarding the seaward boundary, they state that most marine activities affecting the coastal zone are found within the twelve nautical mile jurisdiction, though to accommodate oil and gas development a wider boundary may be necessary (Cicin-Sain, 1993; Cicin-Sain and Knecht, 1998).

For purposes of this research, the coastal study units were not defined with fixed linear widths; rather, they were flexible enough to include the majority of coastal activities and concerns identified. The terrestrial boundary used, $3 \mathrm{~km}$ inland from the low-water mark, was sufficient to capture the majority of resource uses and concerns. The boundary was increased in specific circumstances where it did not provide a comprehensive overview of activities and issues identified. Similarly, the seaward boundary was defined as $10 \mathrm{~km}$ offshore, with exceptions based on specific circumstances.

\section{THE QUESTIONNAIRE, RESULTS AND DISCUSSION}

Qualitative interviews were conducted with 43 individuals over a period of several weeks, during which the researcher lived in the community. Qualitative interviews, or open-ended questions, are interactions between an interviewer and respondents that are flexible and easily adaptable in terms of time required and content. Each individual can provide as much information as he or she wishes. A qualitative interview differs from a quantitative interview in that the interviewer has a general question guide, but not a specific set of questions that must be asked in consistent wording and in a particular order (Babbie, 1998).

Questions were divided into three sections: personal information, study unit prioritization, and identification and prioritization of resource uses and concerns. From the first set of questions, the interviewee's name, role, and affiliation were noted.

\section{Study Units}

The second task of the interviewees was to prioritize the study units presented, assigning to each unit a high, moderate, or low value in terms of ecological, economic, cultural and social considerations, and to justify their choices (see Table 2). The Churchill River estuary (unit 3 ) was given high priority by the greatest number of participants (18 of 43). These results reflect the location of the Churchill River adjacent to town, accessible to most participants. It is one of the coastal areas used most frequently for recreation (boating and fishing) and economic activities involving the port. In contrast, only four individuals identified study unit 9, Knight's Hill, as being of high value. Its distance from town and difficult terrain place this area beyond the point to which most of those interviewed travel. This example is representative of the pattern that characterized the other responses: the closer the proximity of a study unit to the participants, the greater the value they placed on it.

Those interviewed were in large part reluctant to rank one study unit as being of lesser or greater value than another. This may suggest that community members view the entire coastline as being of significant value and are unwilling to document the relative importance of any study unit. The results from those who did prioritize the study 
TABLE 2. Justification for prioritization of study units, as identified during interviews.

\begin{tabular}{rll}
\hline \hline Study Unit & Prioritization & Reasoning provided by participants \\
\hline 1 & Moderate & Recreation, fishing, archaeological sites \\
2 & High & Historical value, tourism, birdwatching, beluga habitat, estuary \\
3 & High & Port, shipping, beluga habitat, tourism \\
4 & High & Town, beluga off-shore \\
5 & High & Airport, lots of activities, birdwatching \\
6 & Moderate & Birdwatching \\
7 & High & Birdwatching, cabins, recreation, ptarmigan hunting \\
8 & High & Polar bears, tundra vehicles, tourism, wildlife management area \\
9 & Moderate & Recreation \\
10 & High & Wapusk National Park, research, polar bear habitat, caribou habitat and hunting \\
11 & High & Wapusk National Park, research, polar bear and caribou habitat \\
\hline \hline
\end{tabular}

units showed consistency with respect to value, indicating similar viewpoints among community members as to the great importance of the coast. Reasons for valuing a unit included both human uses and ecological activities (see Table 2). For example, the Churchill River estuary (unit 3) was cited as being of high importance for its role in the town's economy (port and shipping) and for the beluga habitat provided by the estuary. From results such as this, we can infer that residents are very aware of the role of specific activities in maintaining the well-being of the town and region, in terms of the local economy, recreational opportunities, and ecological processes. These results indicate that each of the 11 study units will need to be given equal consideration in a management plan, since no one unit is significantly more or less important than another.

The identification of study units is subjective and may reflect the interests of the interviewees, but not necessarily the community as a whole. It was anticipated, however, that the overall results would reflect the socioeconomic and ecological diversity of the area, thus providing an acceptable foundation on which to base an understanding of the issues. This classification method enabled each individual to express opinions comfortably and ensured that each had the opportunity to offer a personal assessment of relative significance (Lalumière and Morisset, 1998).

\section{Resource Uses and Concerns}

The third step of the interview involved further documenting the resource-use activities occurring in each study unit and identifying associated concerns. Participants were asked first to describe known coastal activities occurring in the study units and then to identify, categorize (high, moderate, or low priority), and justify their reasoning for attributing coastal concerns to specific study units. Resource-use activities were documented but not prioritized. Using study units served to focus the interviews and facilitated the identification and grouping of activities and concerns in each of the coastal areas.

In total, 43 uses of the coastal area were recorded, the majority of which take place in close proximity to the Town of Churchill. The most abundance and the greatest diversity of activities, including both human uses and ecological functions, were identified for study units 1-8.
Resource uses recorded covered a wide range: personal uses, such as hunting, trapping, and recreational opportunities; use of the area for wildlife habitat, especially by polar bears, belugas, waterfowl, and birds; industrial uses at the port; and even the existence of the Ithaca shipwreck in Bird Cove (see Table 3). Those interviewed discussed impacts of past activities, such as the presence of military buildings and debris, and future activities, such as proposed hovercraft tour routes.

The interviewees were asked to list their concerns with regard to each study unit, as well as to classify each item listed for a specific unit as representing a high, moderate, or low level of concern. A total of 36 concerns were recorded (Table 4). The majority of issues raised were environmental in nature, ranging from the appearance of litter in the town to the well-being of the polar bear population. A wide temporal scale was represented, with many participants citing ongoing concern over the diversion of the Churchill River for hydroelectric development in the 1970s, particularly in terms of continuing negative impacts on fish populations and recreational opportunities. Potential impacts of global warming on the ecosystem were documented as a high concern for the future. These concerns were specifically related to the well-being of the polar bear population: climate change may reduce the fitness of the population because a shorter ice season will force the bears to spend more time on land fasting (Stirling and Derocher, 1993; Stirling et al., 1999). Concern about global warming was also linked to the importance of polar bear tourism to the local economy. In contrast, some members of the community saw climate change as having a positive impact on the town in terms of shipping. For example, shorter ice seasons would allow the port to operate for longer periods.

More concerns were identified for the study units around the town site, and respondents assigned them moderate or high priority. In units $8-11$, located $30-55 \mathrm{~km}$ from the town, fewer concerns were identified, yet those were also rated as being of high priority.

\section{Verification of Results}

The information collected from these interviews was consolidated, tabulated, and mapped to provide a compre- 
TABLE 3. Resource-use activities identified during interviews.

\begin{tabular}{ll}
\hline \hline Airport activities & Recreation \\
ATV use & (camping, biking, beach) \\
Bird habitat/birdwatching & Recreational boating \\
Bird and waterfowl hunting & Recreational fishing \\
Cabins/cottages & Research \\
Caribou habitat/hunting & SCUBA diving \\
Dog compound & Seal hunting \\
Flight routes & Seaweed concentration \\
Gravel/sand pit activities & Site of wreck \\
Hiking & Spaceport \\
Historical/archeological sites & Tourism activities \\
Hovercraft route & Town activities \\
Lodge & Town water supply \\
Marine tank farm activities & Trails \\
Military sites & Training exercises \\
$\quad$ debris, clean-up activities) & Trapping \\
Moose hunting & Tundra vehicle activities \\
Northern lights viewing & Waste management activities \\
Parkland & Whale habitat/activities \\
Polar bear habitat & (watching, hunting, capture) \\
Polar bear control zone & Weir construction \\
Port activities & Winter transportation \\
(construction, dredging) & Wolf hunting \\
& York Factory fee simple lands \\
\hline \hline
\end{tabular}

hensive overview of all the resource-use activities and concerns. Preliminary study results were taken back to Churchill for verification. During an exhibit set up for the community in the Churchill Town Complex, over 90 individuals stopped to discuss study results. Thirteen of these visitors had participated in the earlier interview process. Visitors to the exhibit were asked whether the results shown represented coastal activities and concerns accurately from their perspective. No negative responses were recorded. There was general concurrence with the concerns and activities identified, although it is recognized that this verification method may have been intimidating to some. Study results were presented to high school students to ensure that youth were given an opportunity to participate in these discussions and to educate them about the importance of Hudson Bay and marine management issues. Many of the students commented on the results and discussed how they use the coast. From conversations with youth and other community members, we concluded that Hudson Bay and the Churchill region are rarely included in the school curriculum. It became apparent that students were interested to learn about their immediate surroundings.

\section{EFFECTIVENESS OF THE MODEL}

\section{Comparison of the Working Group and Qualitative Interview Methods}

This study was modeled after Lalumière and Morisset (1998), in terms of dividing the study area into units, prioritizing concerns, and producing summary maps to show the units, activities, and concerns. The primary difference in the conduct of the two studies was the manner in which the consultations took place (Table 5).
TABLE 4. Coastal concerns identified during interviews.

\begin{tabular}{ll}
\hline \hline Akudlik Marsh health & Military debris \\
ATV impacts & Not enough on-going research \\
Birdwatching impacts & Not enough tundra vehicle permits \\
Cancer/birth defect rate & Polar bear well-being \\
Changes to Churchill River dynamics & Port pollution \\
Conflict with hunters & Port accessibility \\
Conflict between tundra vehicle & Potential for fire \\
$\quad$ companies & Resources management activities \\
Damage to archeological sites & Snow goose damage \\
Development & Spraying for insects \\
Dog compound & Town appearance \\
Dredging of port & Train shipments \\
Environmental sustainability & Tundra vehicle damage \\
Garbage & Tundra vehicle regulations \\
Global warming impacts & Vehicle and wildlife interactions \\
Gravel/sand excavation & Wapusk National Park \\
Human safety & management \\
Lodge management & Whale capture \\
Marine pollution & Wildlife Management Area \\
& management \\
\hline \hline
\end{tabular}

Lalumière and Morisset (1998) used a working group scenario: participants were invited to attend meetings in a central location to discuss the project. The working group approach resulted in a relatively small number of participants, as many members missed meetings. In the end, only 15 individuals participated in identifying coastal activities and concerns. The working group methodology was effective, however, in achieving consensus on the most important concerns for each study unit in a relatively short time.

In the individual interview approach adopted for the Churchill study, more individuals were able to participate, since interviews were scheduled at their convenience and at their preferred location. There was no requirement to attend meetings or workshops. This approach facilitated excellent community representation, and should result in a more accurate portrayal of coastal activities and concerns. The interview format with open-ended questions allowed for a great deal of freedom in responding. This may have improved the quality of the information collected; however, it made the results of the qualitative interviews more difficult to quantify and consolidate. Rather than achieving true consensus, as would have been possible with a working group, the study illustrates areas of relatively greater importance to community members.

During a working group meeting, individuals generally have less opportunity to provide input, and they may be influenced by other people's responses. The qualitative interview method gave each participant the opportunity to provide independent responses. On the other hand, the synergies possible with a group effort were not possible with independent interviews. In the working group model, researchers had regular opportunities to provide all participants with information about the study as it evolved. Each participant was presented with the same information as the others. The interview method required the researcher to return to the community to provide updates on the project, and this second visit provided an opportunity to 
TABLE 5. Comparison of the two study methods.

\begin{tabular}{lll}
\hline \hline & Lalumière and Morisset (1998) & This Study \\
\hline Engagement method & Working group. & Qualitative interviews. \\
No. of Participants & 15 & $43+90$ during verification visit. \\
Consensus building & As a group. & Rather than consensus, study illustrates areas of greater importance to community member. \\
Participation & $\begin{array}{l}\text { Answers influenced by group; } \\
\text { more rigid time constraints; } \\
\text { set dates for meetings; } \\
\text { group synergies. }\end{array}$ & $\begin{array}{l}\text { All participants were able to provide independent answers; } \\
\text { no time constraints; } \\
\text { location and interview dates were up to the interviewee; } \\
\text { no group synergies. }\end{array}$ \\
& $\begin{array}{l}\text { Many participants were present } \\
\text { for the same discussions. }\end{array}$ & $\begin{array}{l}\text { Quantity/quality of information exchanged varied between interviews. } \\
\text { Consistency of information }\end{array}$ \\
Study units & $\begin{array}{l}\text { Determined as a group; } \\
\text { time consuming. }\end{array}$ & $\begin{array}{l}\text { Preliminary boundaries determined by researcher; } \\
\text { changes made based on interviews. }\end{array}$ \\
\hline \hline
\end{tabular}

inform the larger community of the study objectives, results, and outcomes. However, all interviewees may not have received the exact same information, since it was during the individual interviews that various interests and topics were explored.

The methods used to classify the study units also differed in the two studies. Lalumière and Morisset (1998) asked the working group to develop the study unit boundaries. While the working group achieved consensus on each study unit and its relevance, this process consumed much of the group's available time, occupying two of the study's four meetings. In contrast, for the Churchill study, tentative study units were identified prior to the field season. Those interviewed were given the opportunity to comment on the placement of the study unit boundaries, resulting in changes to two of those boundaries. Apart from these changes, the study unit placements were satisfactory to the participants. Defining the study units in advance meant that the interviews could focus on identifying activities and prioritizing concerns.

An alternative way of selecting study units would be to ask participants to identify the main conflicts and tradeoffs in the area as a whole and then develop study units around this information. Such an approach might be better suited to a working group: where discussion could take place among the various interested parties, it is likely that strong themes could emerge.

\section{Potential Sources of Bias}

Both this study and that of Lalumière and Morisset (1998) are subject to potential bias. The sample populations did not necessarily represent the composition of the larger population, and the results are subjective since they are based on the perspectives of the interviewees. As Lalumière and Morisset (1998) acknowledge, a different group of participants might have obtained different outcomes. The results, however, do reflect the socioeconomic and ecological diversity of the coast; therefore, they likely constitute a satisfactory basis on which to develop integrated management planning in the area (Lalumière and Morisset, 1998). In our study, a large portion of the Churchill community was represented. The majority of these respondents (70\%) had lived in the town of Churchill for more than five years. As well, the results were verified with 90 individuals or almost $10 \%$ of the town's population.

As previously discussed, the snowball sampling method does not give a statistically representative sample. As a result, in the Churchill study the aboriginal population was underrepresented, as were females and certain age groups. Only 9 of the 43 individuals interviewed were known to be of aboriginal descent, and this could have affected the results. However, there did not appear to be any major differences between the responses of known aboriginal and non-aboriginal participants. During the verification visit, 34 of the 90 visitors to the exhibit were known to be aboriginal, and all of them appeared to agree with the results displayed and discussed. The majority of people interviewed were between the ages of 20 and 64: only two people older than 65 were included, and no participants were under the age of 20. Again, these demographics may have skewed the results. Concern about this potential for bias was allayed during the confirmation visit, when all ages were well represented and all visitors confirmed the results. Finally, interview participants were predominantly male (28 of 43), and this imbalance may have biased the results. However, during the confirmation visit, almost half of the visitors were female, and all appeared to agree with the results presented.

The manner in which concerns were prioritized is another potential source of bias. No activity or concern identified was discounted, regardless of the number of respondents, since each represents the views of some portion of the community. As a result, activities and concerns identified by just one interviewee are given the same weighting as all others. With a larger sample size, or using a working group scenario, the prominence of these activities and concerns might have been diminished. 


\section{CONCLUSIONS}

Several conclusions can be drawn about the modeling process. Despite some sources of bias, the methods produced a comprehensive overview of activities and concerns. Documenting and inventorying these activities and concerns provides a satisfactory basis for engaging interest groups and proceeding with integrated management planning, Adaptations of this model may be appropriate for similar coastal communities, such as those of the Canadian Arctic and Subarctic, which are isolated and have small populations, high aboriginal representation, a dependence on the land, and a strong awareness of coastal resource uses and issues.

This model enables a working relationship between the many interest groups and management agencies that helps to create an atmosphere of mutual respect from which local knowledge and values can be drawn. Community involvement is necessary and desirable for management planning, and through application of this model, advancements can be made toward integrated management. For other communities, existing customary tenure arrangements may need to be used rather than study units. In smaller, less complex coastal areas, the coast could be examined as a whole.

The value of this study will be determined by the usefulness of its results for developing an integrated area management plan. It provides an efficient overview of coastal concerns and activities on which to base future planning efforts. Resolving potential resource-use conflicts and addressing concerns will likely prove to be the greatest challenge for integrated management planning in the region.

The results from this project will assist the integrated management process in Manitoba and may act as a template for inventories elsewhere in Hudson Bay. Integrated management planning is an ongoing process, and resource inventories, as well as management plans, must be reassessed regularly. To date, the integrated management initiative for Western Hudson Bay has proceeded through two workshops and a community tour that included Churchill and six communities of the Kivalliq region of Nunavut. Interest groups involved include government (federal, provincial, territorial, municipal), nongovernmental organizations, co-management boards, First Nations, Inuit, academia, consultants, the mining industry, and the energy sector (hydroelectric). The Hudson Bay Oceans Working Group was formed from the aforementioned groups in fall 2001 to further address integrated management planning for the Western Hudson Bay region. In addition to Churchill, the whole of the Manitoba coast and the Kivalliq Region of Nunavut are included in this initiative.

\section{ACKNOWLEDGEMENTS}

The authors would like to thank Dr. Jack Mathias, Mr. Don Cobb, and three anonymous reviewers for their comments and suggestions. Ms. Dianne Michalak provided assistance in developing the figures. This study was funded by Fisheries and Oceans Canada, the Northern Scientific Training Program, and the Northern Research Fund, through the Churchill Northern Studies Centre.

\section{REFERENCES}

BABBIE, E. 1998. The practice of social research. Belmont, California: Wadsworth Publishing Company.

BEALS, C.S. 1968. Science, history and Hudson Bay. Vols. 1 and 2. Ottawa: Department of Energy and Mines.

CANADA. 1997. Oceans Act. SC 1996, c 31. O-2.4.

CARIBOU VENTURES LIMITED. 1994. Arctic bridge: An overview of trade opportunities between Russia and Canada via the Arctic ports of Churchill and Murmansk. Winnipeg: Caribou Ventures Ltd.

CAYER, A.A., and BIAGI, M. 1994. Community based ocean management strategies. In: Wells, P.G., and Ricketts, P.J., eds. Coastal Zone Canada '94, Cooperation in the coastal zone: Conference proceedings. Vol. 2. Dartmouth, Nova Scotia: Coastal Zone Canada Association, Bedford Institute of Oceanography. 497-513.

CHURCHILL TASK FORCE. 1995. Gateway north: Report of the Churchill Task Force. Winnipeg, Manitoba.

CICIN-SAIN, B. 1993. Sustainable development and integrated coastal management. Ocean and Coastal Management 21: $11-43$.

CICIN-SAIN, B., and KNECHT, R.W. 1998. Integrated coastal and ocean management: Concepts and practices. Washington, D.C.: Island Press.

COOKE, F., ROCKWELL, R.F., and LANK, D.B. 1995. The snow geese of La Perouse Bay: Natural selection in the wild. New York: Oxford University Press.

ENVIRONMENT CANADA. 1994. Reviewing CEPA: Coastal zone management in Canada. Ottawa: Environment Canada.

EUROPEAN COMMISSION. DIRECTORATES-GENERAL. ENVIRONMENT, NUCLEAR SAFETY AND CIVIL PROTECTION, FISHERIES, REGIONAL POLICIES AND COHESION. 1999. Towards a European integrated coastal zone management (ICZM) strategy: General principles and policy options. A reflection paper. Luxembourg: European Communities.

DFO (DEPARTMENT OF FISHERIES AND OCEANS CANADA). 1997. Toward Canada's oceans strategy. Ottawa: Fisheries and Oceans Canada.

- 1998. Toward a Canadian framework for integrated coastal zone management. Unpubl. report from the Advisory Committee on Integrated Coastal Zone Management. Available at: Fisheries and Oceans Canada, 501 University Crescent, Winnipeg, Manitoba R3T 2N6, Canada.

HAWARD, M., and VANDERZWAAG, D. 1995. Implementation of UNCED Agenda 21 Chapter 17 in Australia and Canada: A comparative analysis. Ocean and Coastal Management 29: 279-295.

INSTITUTE FOR RESEARCH ON ENVIRONMENT AND ECONOMY. 1996. Community empowerment in ecosystem management. Ottawa: Institute for Research on Environment and Economy. 
KAY, R., and ALDER, J. 1999. Coastal planning and management. New York: Routledge.

KGS CONSULTING. 1998. Environmental assessment of the port of Churchill. Winnipeg, Manitoba: KGS Consulting.

LALUMIÈRE, R., and MORISSET, J. 1998. Pilot project (stage II): Reference framework for the integrated management of the Les Escoumins-Riviere Betsiamites coastal zone. Unpubl. Joint Report. Sept-Îles, Quebec: Group-conseil Geniva, Quebec, and Habitat Management and Environmental Sciences Branch, Fisheries and Oceans Canada. Available from Fisheries and Oceans Canada, Institut Maurice Lamontagne, Mont-Joli, Quebec G5H 3Z4, Canada.

LGD OF CHURCHILL. 1996. Local government district: Community handout. Churchill, Manitoba.

LUNN, N.J., STIRLING, I., ANDRIASHEK, D., and KOLENOSKY, G.B. 1997. Re-estimating the size of the polar bear population in western Hudson Bay. Arctic 50:234-240.

MANITOBA HOUSING AUTHORITY. 1999. Town of Churchill community profile.

NEWTON, S.T. 2000. Sustainable development for Canada's Arctic and sub-arctic communities: A case study of Churchill, Manitoba. Master of Natural Resources Management thesis, University of Manitoba, Winnipeg.
NRTEE (NATIONAL ROUND TABLE ON THE ENVIRONMENT AND ECONOMY). 1998. Sustainable strategies for oceans: A co-management guide. Ottawa: NRTEE.

SCURA, L.F., CHUA, T.-E., PIDO, M.D., and PAW, J.N. 1992. Lessons for integrated coastal zone management: The ASEAN experience. In: Chua, T.-E., and Scura, L.F., eds. Integrative framework and methods for coastal area management. Manila, Philippines: International Center for Living Aquatic Resources Management. 1-70.

STIRLING, I., and DEROCHER, A.E. 1993. Possible impacts of climatic warming on polar bears. Arctic 46:240-245.

STIRLING, I., LUNN, N.J., and IACOZZA, J. 1999. Long-term trends in the population ecology of polar bears in western Hudson Bay in relation to climate change. Arctic 52:294-306.

TOWN OF CHURCHILL. 1999. The community narrative. Churchill, Manitoba: Town of Churchill.

WILDISH, D.J., and STRAIN, P.M. 1994. Science and coastal zone management. In: Wells, P.G., and Ricketts, P.J., eds. Coastal Zone Canada '94, Cooperation in the coastal zone: Conference proceedings. Vol. 2. Dartmouth, Nova Scotia: Coastal Zone Canada Association, Bedford Institute of Oceanography. 2139-2148. 